\title{
Influence of microstructural heterogeneities on capacity to absorb energy of dual-phase steels
}

Gejza Rosenberg $^{1)}$, Iveta Sinaiová ${ }^{1)}$, L’uboš Juhár ${ }^{2)}$

${ }^{1)}$ Institute of Materials Research, Slovac Academy of Sciences, Watsonova 47, 04001 Košice, Slovac Republic, grosenberg@imr.saske.sk

${ }^{2)}$ Unit GM for Research USSE, U. S. Steel Košice, s. r. o, Vstupný areál US Steel Košice, 04454 Košice, Slovac Republic,

The effect of microstructural banding (or so called segregation bands) on energy absorption capacity of dualphase steels (DP steels) was examined by product of tensile strength and uniform elongation (TS $\times$ UE), as well as by Charpy V-notch impact test. A series of DP steels with different volume fractions of martensite (VFM) was prepared by intercritical annealing at temperatures ranging 740 to $840{ }^{\circ} \mathrm{C}$. It was found that increasing of $\mathrm{VFM}$ has an inverse effect on values TS $\times$ UE and notch toughness. The results on samples with a notch and pre-cycled crack showed that presence of segregation bands influences capacity of steels to absorb the energy in initial stage as well as in stage of crack propagation.

Keywords: dual phase steel, microstructural banding, energy absorption capacity

Acknowledgements

Authors would like to thank VEGA SR grant agency for the financial support of the work that was realized within the project 2/0192/12.

\section{Reference}

[1] http://www.autosteel.org/ /media/Files/Autosteel/Research/Lightweighting/future_generation_passenger_comp artment.ashx.org

[2] KONIECZNY A.: On Formability Assessment of the Automotive Dual-Phase Steels, https://shop.sae.org/technical/papers/2001-01-3075

[3] CHAKRABORTI, P.C., MITRA, M.K.: Microstructure and tensile properties of high strength duplex ferritemartensite (DFM) steels, Materials Science and Engineering A 466 (2007) 123-133

[4] MAZINANI, M., and POOLE, W.J.: Effect of Martensite Plasticity on the Deformation Behavior of a LowCarbon Dual-Phase Steel, Metall. Mater. Trans. A, 38A (2007) 2 328-339

[5] SUN, S., PUGH, M.: Properties of thermomechanically processed dual-phase steels containing fibrous martensite, Materials Science and Engineering A335 (2002) 298-308

[6] AVRAMOVIC-CINGARA, G., SALEH, Ch.A.R., JAIN, M.K. and WILKINSON, D.S.: Void Nucleation and Growth in Dual-Phase Steel 600 during Uniaxial Tensile Testing, Metall. Trans. A, 40A (2009) 12 3117- 3127

[7] JUHAR, L.: Influence of temperature-deformation conditions during rolling on multi-phase steels structure creation and their properties, PhD Thesis, Technical University in Košice, Košice 2009 (in Slovak)

[8] VERHOEVEN, J. D.: A Review of Microsegregation Induced Banding Phenomena in Steels, JMEPEG 9 (2000) 3 286-296

[9] CABALLERO, F.G., GARCÍA-JUNCEDA, A., CAPDEVILA, C. and GARCÍA de ANDRÉS, C.: Evolution of Microstructural Banding during the Manufacturing Process of Dual Phase Steels, Materials Transactions, 47 (2006) 92269 to 2276

[10] YURIOKA, N.: Weldability calculation, http://homepage3.nifty.com/yurioka/exp.html. Accessed November 18 2008.XX

[11] BURÍKOVA, K.: Microstructural nature of multiphase steels, PhD Thesis, Institute of Material Research, SAS in Košice, Košice 2009 (in Slovak)

[12] DELINCÉ, M., BRÉCHET, Y., EMBURY, J.D., GEERS, M.G.D., JACQUES, P.J., PARDOEN, T.: Structureproperty optimization of ultrafine-grained dual-phase steels using a microstructure-based strain hardening model, Acta Materialia 55 (2007) 2337-2350

[13] BAG A., RAY, K., DWARAKADASA, E.S.: Influence of Martensite Content and Morphology on Tensile and Impact Properties of High-Martensite Dual-Phase Steels Metall. Mater. Trans. 30A (1999) 1193-1202 
[14] ROSENBERG, G.: The influence of grain size temperature and stress state on brittle fracture of steel, Kovové materiály,(1996) 4 201-216.

Paper number: M201246

Manuscript of the paper received in 2012-10-01. The reviewers of this paper: Jitka Podjuklova, Ivan Lukac. 